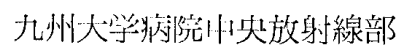

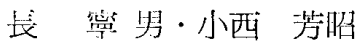

[1阳]

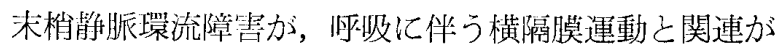
あり，乙れが研究のために横隔膜運動波形を記録し，乙 れを解析しようとするすのである。現在使用している 「シブヤ」のキモグラフでは，乙のままで撮影すると心 蔵キモグラムと同様に波形の大略を知る程度で，波形の 解析には题だ不十分である.

よって波形の拉大法の一つとして波高方问（横）に2 倍昖大すへく，ラスタ一移動趾離（フィルム移動距離） 及び移動速度を2 倍になるよう次の如く政造した。

[改造点]

1）ラスター 現在のラスター移動距離 $(11.5 \mathrm{~mm})$ を, 一つおきに鉛線で間陌を埋めて 2 倍の (23mm) とした。

2) 電気接点 X線開䦌用接点も，2倍の $(23 \mathrm{~mm}$ ! 用 を名别に設けた。

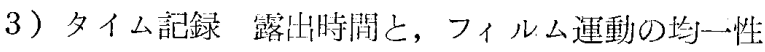
を記鍒するた如に学楽用のメトロノームにより，0.5 秒 蔍の信号を作り，ラスタ一の前面に取付けたマグネット により，乙の偣甼をフィルムに写込むようにした。

ラスターは筸通用 $(11.5 \mathrm{~mm})$, 横隔膜用 $(23 \mathrm{~mm})$ の 2 枚を入れかえるととにより，接点は切加えによって，何 れにも使用可能である。

〔撮影法】

フィルム移動汒により，想者は位で，不横陪膜を約 5 秒で撮影する。

[絬果]

横 2 佔门抬大によって, 波战対振幅の比が $1: 1$ 亿近つ き，没形の解析考容易にした。

0.5 秒每の信号の記録により，その数は露出時間を表 し，また等間隔であることは，フィルムが等速運動をし

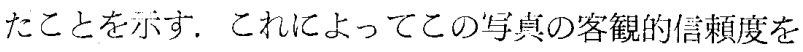
高めるととができた。

\section{8. 定位脳手術簡易頭部固定撮影台の試作}

静网労災病院放射線科

（部是 永丰 純） 鈴木 忠司・松村 忠範 山口正之·村松 官司

定位脸手術は比知のように，大脳深部に存在する基底 核の特定部位に破坮栄を作成して不随意運動症, てんか

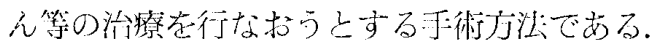

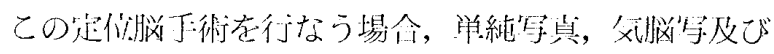
術け，術後に撮影される写真が同一ポシションニングで
なければならず，手術が長時間になる可能性があるので その固定が大変難かしい, 我々は婜者の負担を出米るだ け少なくするとともに，患者が動いても中心点圭せる 事によりポジショニングが同一となるような，また撮影 の祭は頭部孛動汃す事なく, 正側 2 方向撮影の可能な頭 部固定撮影台を試作した.

支持台及び側面の固定板は，アクリルを使用し側面像 において後頭部が久けない様中心部を高くし，また支持 吉の协心に十字のマークを入れ，X線管球の十字投光器 と合せる事により常に，X線束中心が確認出来る。

頭部を実際に本装䈯に乗せた場合，後頭部の中心は， 交持台の下の鏡で確認する様にした。しかし頭部が影に なって中心が見にくい為, 豆電球で照明した。

固定板のストッパーはX線吸収の少ない物質を使用し， フィルムは正面の場合支持台の下にカセッテ受台を設け， 侧面は固定板の外の $\mathrm{Al}$ 製の庄迫板で設䈯し，拡大率が 小さくなるよう被写体, フィルム間距離を出米るだけ短 くした.

また手術が後頭部からす可能な様になっている.

59. Auto-Cassette (NC-312) の使用経過報告 第2 報

三和銀行東京猃療所 八重沢良司・○木村敏昭 東大病院中央放射線部 中島 準次

[目的]

第24回総会で Auto-Casstte（NC-311）の使用経過圭 報告したが，今回はNC-311 型を更に改良した NC-312 型を使用して脑部直接X線検查を病院と移動車による集 団検診で実施した場合に作業能率が更に向上したので報 告する。

\section{据置時 (病院)}

Film set time の短縮で患者の街ち時間が少なくなっ た. No Inter reef Film の使用で Inter reef の处分が ない. Marking が一间照射方式で Marking の miss が なくなった。

移動時 ( $\mathrm{X}$ 線車搭載)

在来の間接撮影に比較して同撮影作数による作業能率 は低下しなかった，X線車走行時の振動, 多少の左右傾 斜時の作動使用，環境の変化等による事故及び故障はな かった。

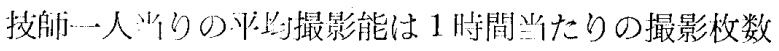
は NC-312 型（1 size）で80枚 NC-312 型（3 size）60枚 Cassette.では40枚であった。 


\begin{tabular}{|c|c|c|}
\hline & $\mathrm{NC}-312$ 型 & Casstte \\
\hline $\begin{array}{l}\text { 技们 } 1 \text { 人当たり } \\
の \text { 処 理 能 }\end{array}$ & 多( (80枚/毎時) & 少い(40枚/伍時) \\
\hline Film 交 換 & $\begin{array}{l}\text { marking } 1 \text { size } \\
1 \text { 回に50枚 }\end{array}$ & 1 枚每 \\
\hline Cassette 交換 & 1 size 50 撮影每 & 撮影每 \\
\hline 技師の移動距離 & 短 い & 長い \\
\hline marking & $\begin{array}{l}\text { 撮影時（早く正 } \\
\text { 確） }\end{array}$ & $\begin{array}{l}\text { 暗室で Print } \\
\text { たは現像後記入 }\end{array}$ \\
\hline
\end{tabular}

\section{[結果]}

Auto-Cassette の使用で全体の作業量が減少し Film set time の短縮で撮影処理能が向上した。

直接撮影による検診に使用できた。

使用頻度の高い大角, 大四切へ magazine の大型化を 댁ㅇ.

\section{0. フローティングテーブルとフィルムサイズ連動自 動多重絞り機構の設計}

京都市立病院
森川 進·声田 弘
島津製作所
河合 泰三・増田 信男

\section{1、X線撮影装睓標準規格とX線写真の質}

信州大学医学部放射線医学教室 春日“敏夫

倍州大学付属病院中央放射線部 丸儿静雄 電気化学工業. K.K

青海工場付属病院レントゲン部 ○侀藤 䳡光 主野県松本市医師会レントゲン部 西村 良治

备々のX線装置のX線エネルギーとX線出力を標潐化 することは，X線撮影条件に普遍性をむたせる意味で重 要である，我々は，装置のエネルギーと出力を簡単に， 定量的に比較する方法を提案した。すすなわち，Al 階段 を一定の条件で撮影し，一定の条件で自動現像して黒化 度階段X線写萁を得た。乙のX線写真の黒化度と $\mathrm{Al}$ 厚 との間には次に示す(3)式の加く比例関係が成立する部分 がある。

$$
\begin{gathered}
I=B \cdot I_{0} \cdot e^{-\mu t} \\
D=\gamma \cdot \log I-C
\end{gathered}
$$

(1)(2)から $D=\left(D_{0}+\gamma \cdot \log B\right)-\gamma \cdot \mu \cdot$

但し, $I: \mathrm{Al}$ 階段透過後のX線量

$I_{0}: \mathrm{Al}$ 階段透過前のX線量
$B$ : ビルドアップ係数 $\mu$ : 線吸収係数

$t: \mathrm{Al}$ の厚さ

$\gamma: X$ 線フィルム特性:曲!線の $\gamma$

$D: \mathrm{Al}$ 階段 $(\mathrm{Al}$ 厚=t) のX線写真具化度

$D_{0}: \mathrm{Al}$ 厚が $O(t=0)$ ○線写真黑化度

この直線部分の勾配 $(\gamma \cdot \mu)$ を我々は contrast factor と呼び， $\gamma$ が一定となる条件を渾すととにより，X線エ ネルギーを表わすすのとした，さらに，X線写真の黒化 度が 1.6 となる Al 厚を求めX線䁷を表わすものとし た。

我々は，長野県，新潟県下 21 施設の装置について，X 線エネルギーとX線量を比較したところ大きなばらつき を示した。 X線写真的な観点から装置の比較をした点で 意味があると考える。また，自動現像機の普及等に上り 簡単な撮影条件の較正法として利用でさると考え今後さ

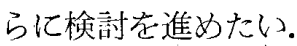

\section{X 線曝射時間の一測定法}

\author{
九大病院放射線科 \\ 竹井力 \\ 九大榇療放射線技師学校 \\ 小山田 即 \\ 九大病院中央放射線部 \\ O坂本 弘巴
}

近時，撮影技術の進歩に伴い短時間曝射が行なわれる 様になり，特にシネパルス撮影等に扎いて $\mathrm{m} \cdot \mathrm{sec}$ オ一 ダーの曝射が行なわれる。乙れらの曝射洔間の測定は従 来のサイクルカウンター, 管電流の通電時間をシンクロ スコープで測定する方法，ストロボ法，等速運動のボケ から算出する写真法等によるむの，また螢光量計等によ り曝射時間の測是が行なわれているが我々はシンチレー

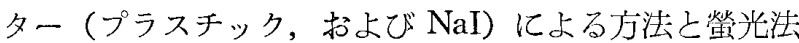

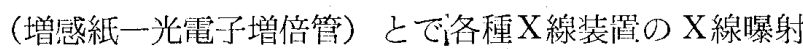
時間を測定しました。

[使用X線発生装置]

1.コンデンサー装置

大阪レントゲン SR-100M-1

2. 単相全波整流装睨

東芝 KXO-15

3. 三相全波整流装置

Elema-Schönander

Triplex Angiomatic 1023 (心臟III管撮影装 置)

[方法]

各装置からのX線をシンチレーターには約 $1 \mathrm{~mm}^{2}$ ，増 